\title{
Magnesium-lithium alloys with TiB and Sr additions
}

\author{
Mariusz Król ${ }^{1}$
}

Received: 15 January 2019/Accepted: 27 April 2019/Published online: 20 May 2019

(C) The Author(s) 2019

\begin{abstract}
The ultralight hypoeutectic $\alpha$-phase $\mathrm{Mg}-4.5 \mathrm{Li}-1.5 \mathrm{Al}$ alloy and hypereutectic $\beta$-phase $\mathrm{Mg}-12 \mathrm{Li}-1.5 \mathrm{Al}$ alloy in as-cast state were fabricated and subjected to modification by 0.2 mass $\% \mathrm{TiB}$ and 0.2 mass $\% \mathrm{Sr}$ grain modifiers. The crystallisation sequence of $\mathrm{Mg}-\mathrm{Li}-\mathrm{Al}$ alloys has been investigated in detail by using thermal-derivative analysis and microstructural observations. The presented work includes the effects of grain refiners on grain size and microstructure and thermal events registered during crystallisation of ultralight $\mathrm{Mg}-\mathrm{Li}-\mathrm{Al}$ alloys by recording and analysis of the temperature vs time, i.e. as $T_{\mathrm{N}}, T_{\alpha}, T_{\beta}, T_{\eta(\mathrm{LiAl})}$ and $T_{\mathrm{SOL}}$. Microstructure and phase observation has been done by light microscope, X-ray diffraction and energy dispersive X-ray spectroscopy. The changes of characteristic temperature points for phase transformation are studied in detail. Due to the addition of 0.2 mass $\% \mathrm{TiB}$ and $0.2 \mathrm{mass} \% \mathrm{Sr}$, the grain structure of the alloy was refined, and mechanical properties were improved. When a $\mathrm{TiB}$ and $\mathrm{Sr}$ added simultaneously, the average grain size of the analysed alloys strongly decreases. When the $\mathrm{TiB}$ or $\mathrm{Sr}$ content was severally added, a low effect of improvements of mechanical properties was observed. With the TiB and Sr content, the liquidus and solidus decrease gradually.
\end{abstract}

Keywords Mg-Li · Grain refiners · Thermal-derivative analysis $\cdot$ Mechanical properties

\section{Introduction}

Looking for new materials that meet the requirements of modern constructions, minimising mass while maintaining high properties and even increasing durability lead to the development and testing of magnesium alloys belonging to the group of light alloys [1-3].

This material has been used in various industries for many decades, showing a growing trend and increasing its popularity, from the automotive or aerospace industries, through electronic, sports, weapons to the space industry. Magnesium alloys give the potential for mass and associated energy savings in both the automotive and aerospace applications as all possess the highest strength-to-mass ratio to basic structural alloys. Despite the expensive cost, this potential advantage has led to a recent rise in interest on the cast and wrought magnesium components [2-4].

Mariusz Król

mariusz.krol@polsl.pl

1 Institute of Engineering Materials and Biomaterials, Faculty of Mechanical Engineering, Silesian University of Technology, Konarskiego 18a St., 44-100 Gliwice, Poland
The unfavourable tendency of using only standard $\mathrm{Mg}$ alloys has led to limiting the development of more demanding and complex varieties. Discontinued due to insufficient footing properties in the past, after their improvement they are experiencing resurgence and placing today the third place among the numerous commonly used materials in the automotive industry [5-7].

The main focus is on the modification of magnesium using alloying elements and the development of the manufacturing process, which is high-pressure casting, characterised by ever better production efficiency and a beneficial effect on the properties of the material [8].

One of the tested magnesium alloys is those with the addition of lithium, forming ultralight alloys with high stiffness and good plastic deformability. Despite the features mentioned, their use is still limited due to insufficient strength and corrosion resistance. It is worth noting that research and hopes about $\mathrm{Mg}-\mathrm{Li}$ alloys, their modifications and finding of the gold in the case of alloy additives are being carried out all over the world $[9,10]$.

To magnesium alloys, grain refinement is essential as an excellent grain size generally leads to developed mechanical features and a more uniform concentration of 
secondary phases and solute elements on a fine scale which results in greater machinability [11-14].

It is well identified that $\mathrm{Al}-5 \mathrm{Ti}-\mathrm{B}$ master alloy is an efficient grain refiner in aluminium alloys; however, nowadays researchers start to pay increased attention to the influences of $\mathrm{Al}-\mathrm{TiB}$ additions on the grain size of $\mathrm{Mg}$ based alloys.

This work focused on analysis of the crystallisation sequence of the ternary hypoeutectic single- $\alpha$-phase $\mathrm{Mg}-$ $4.5 \mathrm{Li}-1.5 \mathrm{Al}$ and hypereutectic $\beta$-phase $\mathrm{Mg}-12 \mathrm{Li}-1.5 \mathrm{Al}$ alloys detail by first derivative, mainly, on the analysis of critical temperatures and transitions during crystallisation. The microstructure observation, computer-aided cooling curve analysis and X-ray diffraction (XRD) were applied for phase identification to define the influence of applied grain modifiers.

\section{Experimental}

The as-cast magnesium-lithium-aluminium alloys: $\mathrm{Mg}-$ 4.5 $\mathrm{Li}-1.5 \mathrm{Al}$ and $\mathrm{Mg}-12 \mathrm{Li}-1.5 \mathrm{Al}$, were used in this study. The analysed magnesium alloys were selected based on a binary system of $\mathrm{Mg}-\mathrm{Li}$ diagram (Fig. 1) characterised as single $\alpha$ - and $\beta$-phase structure. Commercial pure magnesium (min. 99.5\%), lithium (99.9\%) and aluminium (99.98\%) and $\mathrm{TiB}$ and $\mathrm{Sr}$ were added into mild steel crucible placed in induction heater VSG 02 from the Balzers Company. For the production of alloys, high-purity $\mathrm{Mg}$ ingots were smelted in a steel crucible in argon-protective atmosphere at $700-720{ }^{\circ} \mathrm{C}$ at a pressure of 650 torr, to reduce the evaporation of elements. The alloys were cast gravitationally into the cold mould of graphite in rod-

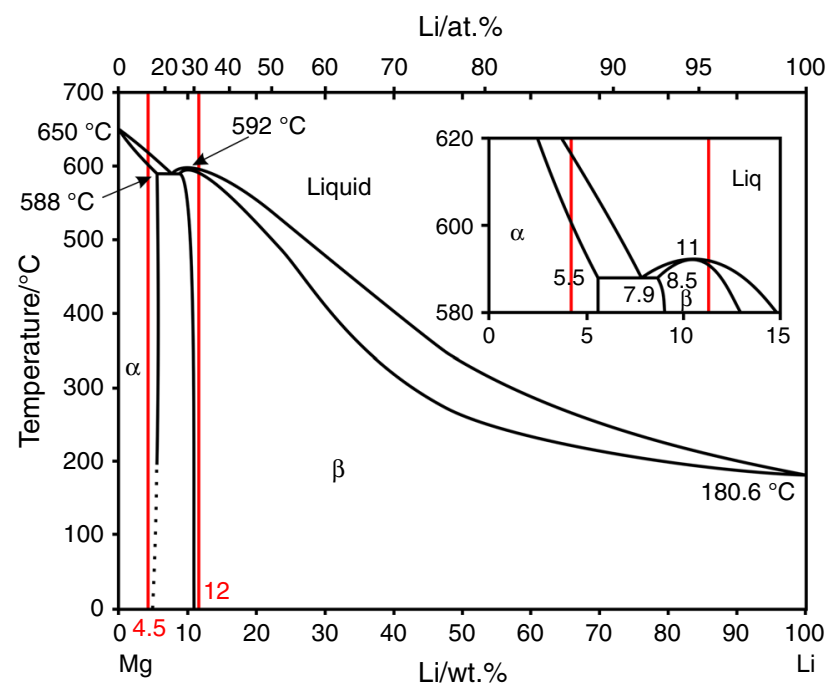

Fig. 1 Binary system of analysed Mg-Li alloys [15] shaped ingots with dimensions $\varnothing 20 \times 100 \mathrm{~mm}$. The analysis of chemical composition of elements in analysed ultralight $\mathrm{Mg}-\mathrm{Li}$ alloys was specified by the ICP-OES method. The measurements results of the analyses are listed in Table 1. The chemical composition of used grain refinements is given in Table 2. The master alloys were provided by Institute of Non-Ferrous Metals, Light Metals Division in Skawina, Poland.

Measurements of $\mathrm{Al}, \mathrm{Li}, \mathrm{B}, \mathrm{Si}, \mathrm{Ti}, \mathrm{V}, \mathrm{Fe}, \mathrm{Sr}$ and $\mathrm{Ca}$ contents in the obtained solutions were made using the inductively coupled optical emission spectrometer with inductively coupled plasma (ICP-OES) Optima $5300 \mathrm{~V}$, manufactured by PerkinElmer. The samples were taken in a mixture of nitric $(\mathrm{V})$ and hydrochloric acids with the addition of hydrofluoric acid.

The thermal-derivative analysis (TDA) of melting and solidification series was carried out using the Universal Metallurgical Simulator and Analyser (UMSA). Specimens for thermal treatment were cut from the same position of the cast ingots and processed into cylinders of $18 \mathrm{~mm}$ in diameter and $20 \mathrm{~mm}$ in length. The data for TDA were collected using a high-speed National Instruments data acquisition system linked to a personal computer. The signal in the form of heating and cooling curves was measured during the melting and solidification cycles. The temperature versus time and first derivative versus temperature were calculated and plotted. One shielded $K$-type thermocouple was immersed in the melt from the top. The average cooling rate between liquidus and solidus temperature was approx. $0.6{ }^{\circ} \mathrm{C} \mathrm{s}^{-1}$. The Fityk software was used for the analysis of obtained results. In order to determine a crystallisation process of analysed materials, the cooling curves and corresponding first derivative were plotted. The baseline was determined based on the Newtonian method. The baseline has been predicted by sixth polynomial fitting $(\mathrm{d} T / \mathrm{d} t)_{\mathrm{BL}}=a_{0}+$ $a_{1} T+a_{2} T^{2}+a_{3} T^{3}+a_{4} T^{4}+a_{5} T^{5}+a_{6} T^{6}$. The sixth-order polynomial yields a correlation coefficient higher than 0.98 . Thermal-derivative analysis was made at least three times per alloy. The presented values in tables are average values.

A small cross section was cut from the same part of the cast alloy sample for metallographic observations. The microstructure and morphology of the analysed materials were observed using Leica microscope with Q-WinTM image analyser software. The linear intercept method was applicable for average grain size measurements. To reveal a microstructure of analysed alloys, etchant composed of $1 \mathrm{~mL} \mathrm{HNO}_{3}, 24 \mathrm{~mL}$ water and $75 \mathrm{~mL}$ ethylene glycol was used. The etchant time was approx. $10 \mathrm{~s}$.

The alloy was subjected to X-ray diffraction (XRD) using a X'Pert diffractometer to analyse the alloy sample composition and phases. For X-ray diffraction analysis, a 
Table 1 Analysed chemical composition of the as-cast Mg-Li-Al alloys

\begin{tabular}{|c|c|c|c|c|c|c|c|c|c|c|}
\hline An alloy & $\mathrm{Li}$ & $\mathrm{Al}$ & $\mathrm{Si}$ & B & $\mathrm{Ti}$ & $\mathrm{Sr}$ & $\mathrm{V}$ & $\mathrm{Ca}$ & $\mathrm{Fe}$ & $\mathrm{Mg}$ \\
\hline $\mathrm{Mg}-4.5 \mathrm{Li}-1.5 \mathrm{Al}$ & 4.64 & 1.86 & - & - & - & - & - & - & - & Balance \\
\hline $\mathrm{Mg}-4.5 \mathrm{Li}-1.5 \mathrm{Al}+0.2 \mathrm{TiB}$ & 4.66 & 1.80 & 0.0052 & 0.0019 & 0.0069 & - & - & - & 0.0019 & Balance \\
\hline $\mathrm{Mg}-4.5 \mathrm{Li}-1.5 \mathrm{Al}+0.2 \mathrm{Sr}$ & 4.63 & 1.80 & 0.030 & - & - & 0.019 & - & 0.018 & - & Balance \\
\hline $\mathrm{Mg}-4.5 \mathrm{Li}-1.5 \mathrm{Al}+0.2 \mathrm{TiB}+0.2 \mathrm{Sr}$ & 4.63 & 1.85 & 0.041 & 0.0012 & 0.0042 & 0.021 & $<0.001$ & 0.0023 & $<0.001$ & Balance \\
\hline $\mathrm{Mg}-12 \mathrm{Li}-1.5 \mathrm{Al}$ & 12.00 & 1.80 & - & - & - & - & - & - & - & Balance \\
\hline $\mathrm{Mg}-12 \mathrm{Li}-1.5 \mathrm{Al}+0.2 \mathrm{TiB}$ & 12.00 & 1.75 & 0.040 & 0.0021 & 0.0091 & - & $<0.001$ & - & 0.0012 & Balance \\
\hline $\mathrm{Mg}-12 \mathrm{Li}-1.5 \mathrm{Al}+0.2 \mathrm{Sr}$ & 12.00 & 1.78 & 0.027 & - & - & 0.025 & - & 0.0053 & - & Balance \\
\hline $\mathrm{Mg}-12 \mathrm{Li}-1.5 \mathrm{Al}+0.2 \mathrm{TiB}+0.2 \mathrm{Sr}$ & 12.00 & 1.77 & 0.028 & 0.0028 & 0.013 & 0.020 & $<0.001$ & 0.0067 & 0.0017 & Balance \\
\hline
\end{tabular}

Table 2 Chemical composition of $\mathrm{TiB}$ and $\mathrm{Sr}$ master alloys used as grain refinements

\begin{tabular}{lllllllll}
\hline An alloy & $\mathrm{Ti}$ & $\mathrm{B}$ & $\mathrm{Fe}$ & $\mathrm{Si}$ & $\mathrm{V}$ & $\mathrm{Sr}$ & $\mathrm{Ca}$ & $\mathrm{Al}$ \\
\hline TiBor & 4.9 & 0.95 & 0.17 & 0.06 & 0.09 & - & - & Balance \\
AlSr & - & - & 0.13 & 0.08 & - & 10.7 & $<0.10$ & Balance
\end{tabular}

Co target, a scan rate of 0.03 step/s and a scan range of $2 \theta$ of $30-110^{\circ}$ were used.

The Zwick ZHR 4150 TK hardness tester in the HRF scale was used for hardness measurements.

\section{Results and discussion}

Figure 2 displays the X-ray diffraction patterns of analysed $\mathrm{Mg}-\mathrm{Li}-\mathrm{Al}$ alloys. The alloys with 4.5 mass $\%$ lithium consisted of the single $\alpha-\mathrm{Mg}$ phase (solid solution of lithium in magnesium). The XRD profile of 12 mass $\% \mathrm{Li}$ alloy demonstrates that the analysed alloy consists of single-phase- $\beta$-Li phase (a solid solution of magnesium in lithium). The presented XRD results are faithful with analysis of microstructure using a LOM (Fig. 3). The XRD analysis revealed that aluminium does not create any new phases, which indicates that aluminium is present in a solid solution. Moreover, addition of TiB and Sr does not affect the appearance of new phases.

Figures 3 and 4 show the microstructure of $\mathrm{Mg}-4.5 \mathrm{Li}-$ $1.5 \mathrm{Al}$ and $\mathrm{Mg}-12 \mathrm{Li}-1.5 \mathrm{Al}$ in as-cast alloys and after treatment by $\mathrm{TiB}$ and $\mathrm{Sr}$. When $\mathrm{TiB}$ and $\mathrm{Sr}$ were added to the alloy, the $\alpha$-magnesium and $\beta$-lithium grains in the alloy were refined, and the grain morphology becomes with a granular shape.

In summary, it can be concluded that the microstructure is formed of $\alpha$ - and $\beta$-phases which is consistent with the
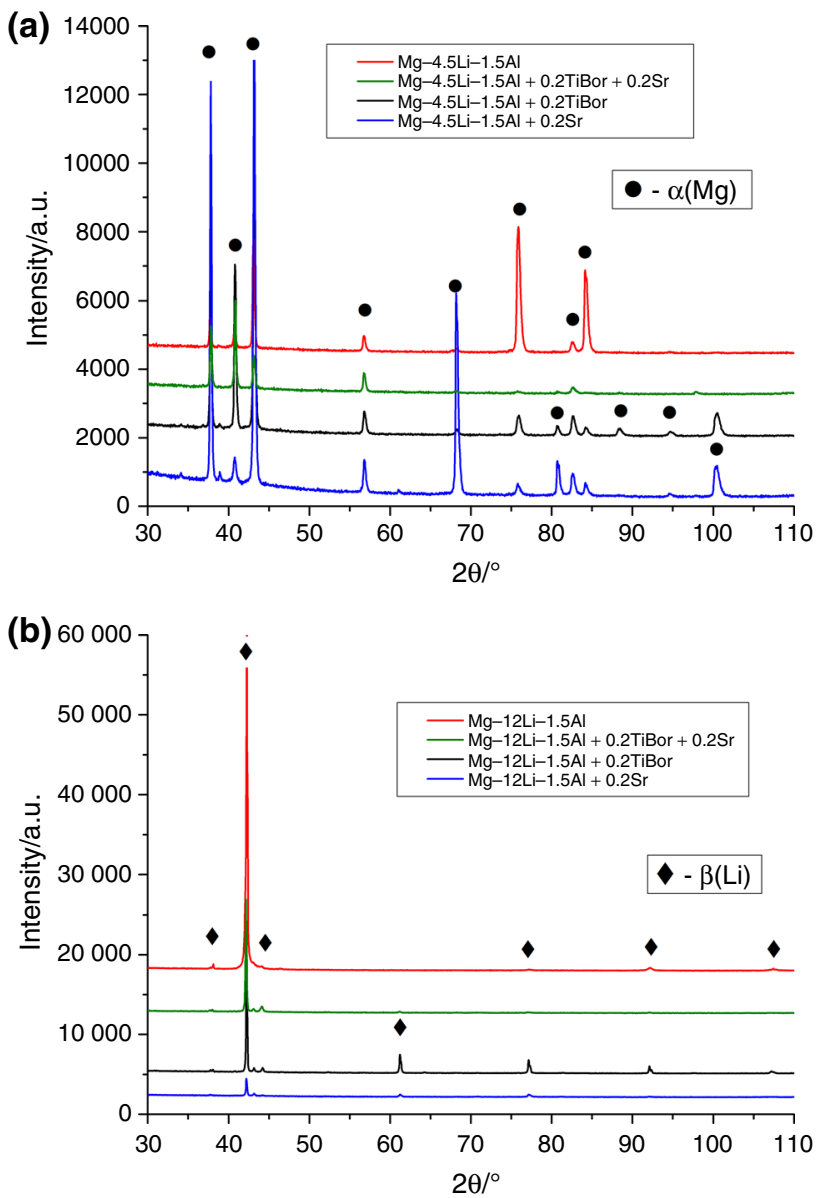

Fig. 2 XRD profiles of: a $\mathrm{Mg}-4.5 \mathrm{Li}-1.5 \mathrm{Al}$ and $\mathbf{b} \mathrm{Mg}-12 \mathrm{Li}-1.5 \mathrm{Al}$ treated by $\mathrm{TiB}$ and $\mathrm{Sr}$ as grain modifiers

Mg-Li phase diagram [16, 17]. XRD analysis confirms the occurrence of main phases in analysed materials.

Measurements of the average grain size of analysed alloys determined by line intersect method exhibit that the modification level is different for every analysed alloys (Figs. 3, 4). When the TiB is applied, a notable decrease in 
Fig. 3 Microstructures of $\mathrm{Mg}-$ $4.5 \mathrm{Li}-1.5 \mathrm{Al}$ in as-cast state (a), treated by $\mathrm{TiB}(\mathbf{b})$ and $\mathrm{Sr}(\mathbf{c})$ and $\mathrm{TiB}+\mathrm{Sr}(\mathbf{d})$
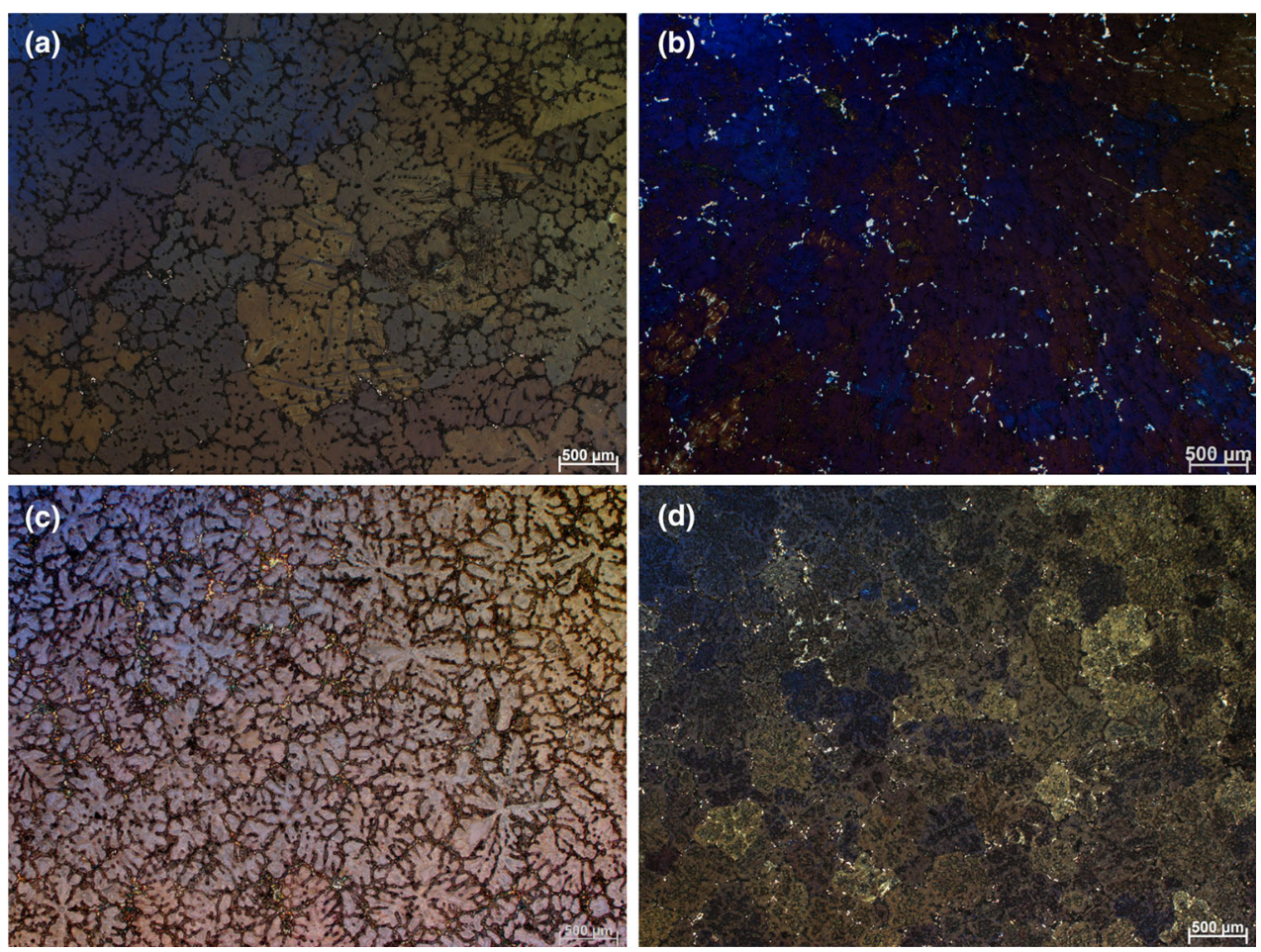

average grain size is observed. The grain size of $\mathrm{Mg}-$ 4.5 $\mathrm{Li}-1.5 \mathrm{Al}$ alloy decreased from 996 to $523 \mu \mathrm{m}$ with 0.2 mass\% TiB (Fig. 5). The measurements exhibit that the application of $\mathrm{Sr}$ reduces the average grain size of $\mathrm{Mg}-$ $4.5 \mathrm{Li}-1.5 \mathrm{Al}$ alloy to $630 \mu \mathrm{m}$, while the simultaneous application of $\mathrm{TiB}$ and $\mathrm{Sr}$ causes a decrease in average grain size to $439 \mu \mathrm{m}$.

Measurements of average grain size of $\mathrm{Mg}-12 \mathrm{Li}-1.5 \mathrm{Al}$ alloy present that application of $\mathrm{TiB}$ as a grain refinement causes the reduction in average grain size from 628 to $385 \mu \mathrm{m}$. The measurements exhibit that the application of $\mathrm{Sr}$ has influence on a decrease of average grain size to $483 \mu \mathrm{m}$, while the addition of $\mathrm{TiB}$ and $\mathrm{Sr}$ simultaneously decreased the average grain size to $394 \mu \mathrm{m}$. Moreover, it can be noticed that with an increment of Li content from 4.5 to 12 mass\%, a decrement of average grain size can be observed.

Measurements of hardness according to the Rockwell method in F scale of alloys after thermal treatment display that the grain refinements affect the average hardness of analysed alloys (Fig. 6). When 0.2 mass\% of TiB is added, the significant increment of average hardness in the $\mathrm{Mg}-$ 4.5 $\mathrm{Li}-1.5 \mathrm{Al}$ alloy from 34 to $40 \mathrm{HRF}$ can be observed. The measurements indicate that the application of Sr slightly reduces the average hardness of $\mathrm{Mg}-4.5 \mathrm{Li}-1.5 \mathrm{Al}$ alloy to $31 \mathrm{HRF}$; meanwhile, the application of $\mathrm{TiB}$ and $\mathrm{Sr}$ simultaneously causes increases in average hardness to 44 HRF. The same situation is observed when the 0.2 mass $\%$ of $\mathrm{TiB}$ is added to analysed $\mathrm{Mg}-12 \mathrm{Li}-1.5 \mathrm{Al}$ alloy; i.e. significant increment of average hardness from 70 to 79 HRF can be observed. The results indicate that the application of Sr slightly decreases the average hardness of $\mathrm{Mg}$ $12 \mathrm{Li}-1.5 \mathrm{Al}$ cast alloy to $75 \mathrm{HRF}$, and similarly, the application of $\mathrm{TiB}$ and $\mathrm{Sr}$ simultaneously causes a decrement in average hardness to 73 HRF. Moreover, it can be noticed that with an increment of $\mathrm{Li}$ content from 4.5 to 12 mass \%, an increment of the average hardness of analysed alloys can be observed.

The solidification sequence of as-cast $\mathrm{Mg}-4.5 \mathrm{Li}-1.5 \mathrm{Al}$ alloy (Fig. 7a) and after addition of 0.2 mass $\% \mathrm{TiB}$ (Fig. 7b) and 0.2 mass\% Sr (Fig. 7c) and 0.2 mass\% TiB and $\mathrm{Sr}$ (Fig. 7d) has been analysed by computer-aided cooling curve method (Table 2). Figure 7a exhibits three lines, i.e. cooling curve, crystallisation curve and baseline that were basis for establishing critical events during crystallisation process. Analysed $\mathrm{Mg}-\mathrm{Li}-\mathrm{Al}$ alloy with 4.5 mass $\% \mathrm{Li}$ and four well-defined reactions are recognised, i.e. at $606.06{ }^{\circ} \mathrm{C}\left[1-T_{\mathrm{N}}-\right.$ nucleation temperature (liquidus temperature) $], \quad 600.53{ }^{\circ} \mathrm{C} \quad\left(2-T_{\alpha, G}-\alpha-\mathrm{Mg}\right.$ growth temperature), nucleation of $\eta(\mathrm{LiAl})$ phase at $545.38^{\circ} \mathrm{C}$ and $524.17{ }^{\circ} \mathrm{C}$ ( $T_{\text {SOL }}$-solidus temperature). The TDA analysis revealed that the addition of $\mathrm{TiB}$ and $\mathrm{Sr}$ does not affect the appearance of new reactions. Results from the thermal-derivative analysis (Table 3) present that the application of 0.2 mass $\% \mathrm{TiB}$ and $\mathrm{Sr}$ causes changes in the nucleation temperature, i.e. from 606.06 to $602.51{ }^{\circ} \mathrm{C}$, and decrement in solidus temperature from 524.17 to $491.23{ }^{\circ} \mathrm{C}$ of analysed alloys. Addition of grain 
Fig. 4 Microstructures of $\mathrm{Mg}-$ $12 \mathrm{Li}-1.5 \mathrm{Al}$ in as-cast state

(a) and treated by $\mathrm{TiB}$ (b) and $\mathrm{Sr}(\mathbf{c})$ and $\mathrm{TiB}+\mathrm{Sr}(\mathbf{d})$
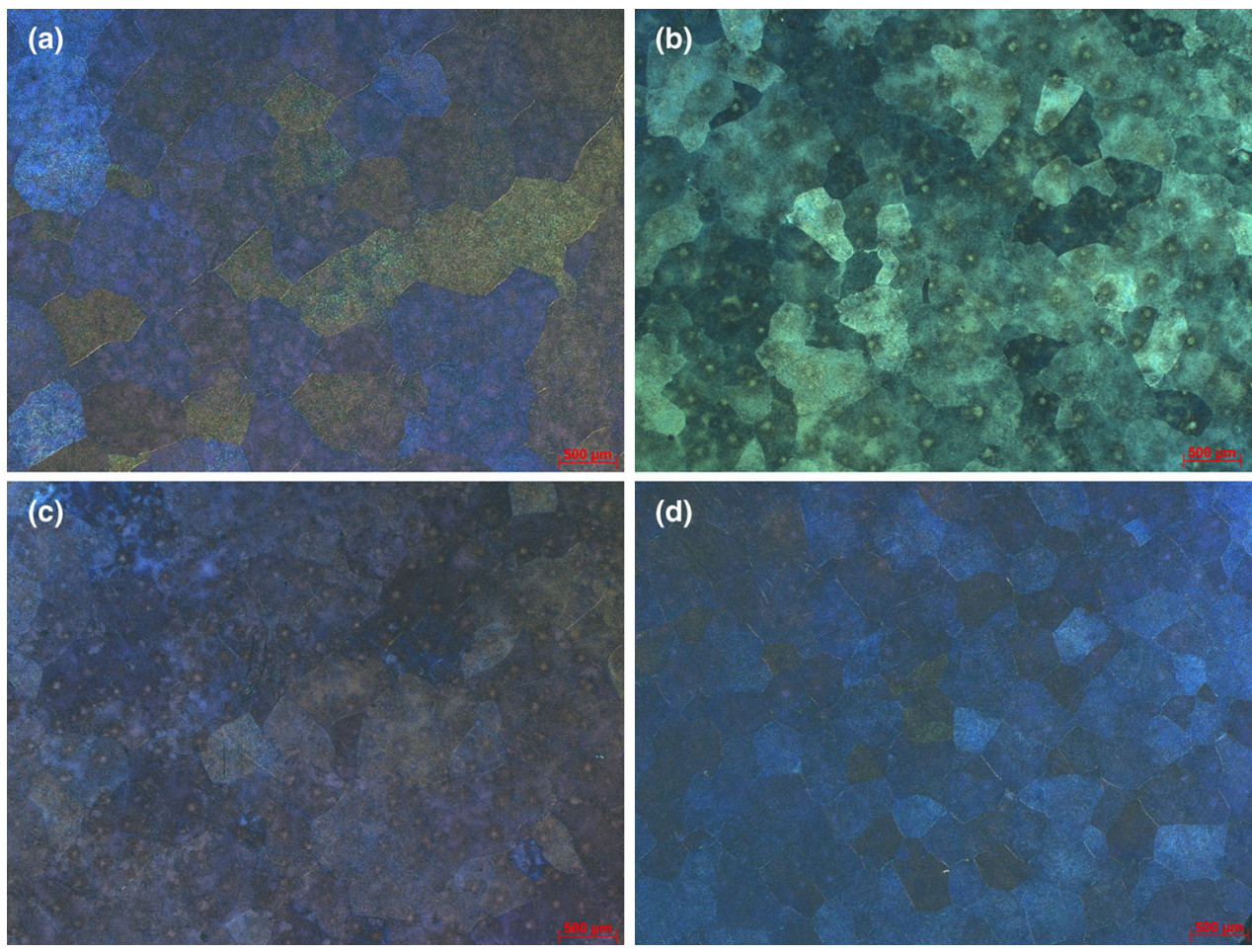

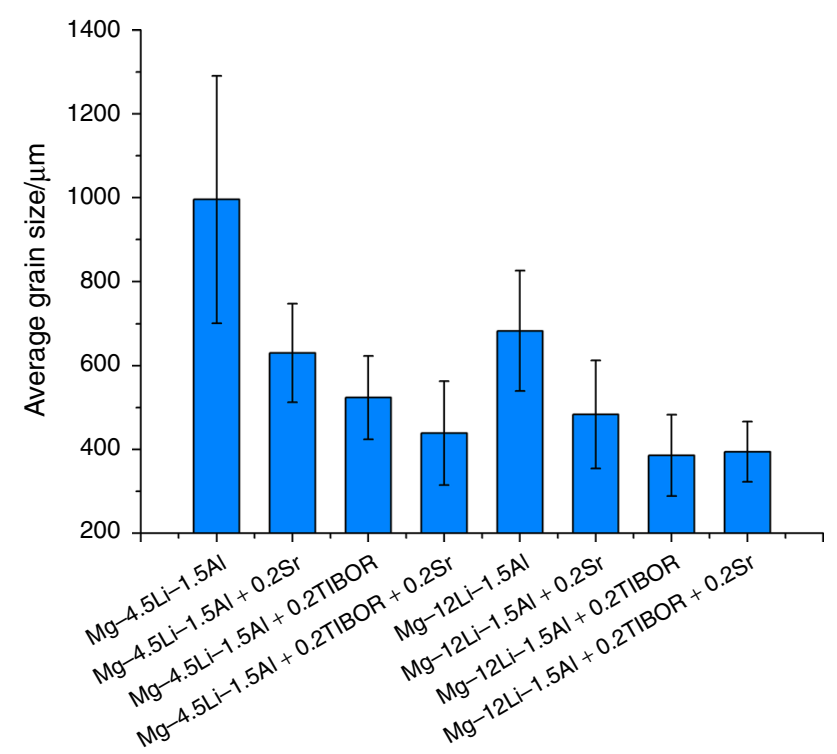

Fig. 5 Variation of grain size of as-cast alloys with the addition of $\mathrm{TiB}$ and $\mathrm{Sr}$ grain modifiers

refinements causes slight decrement in $T_{\alpha, \mathrm{G}}-\alpha-\mathrm{Mg}$ growth temperature from 600.53 to 597.25 when $\mathrm{TiB}$ is added, to 599.09 when $\mathrm{Sr}$ is added and 598.14 when $\mathrm{TiB}$ and $\mathrm{Sr}$ are added simultaneously. The solidification period at the cooling rate of $0.6^{\circ} \mathrm{C} \mathrm{s}^{-1}$, in $\mathrm{Mg}-4.5 \mathrm{Li}-1.5 \mathrm{Al}$ and $\mathrm{Mg}-$ $12 \mathrm{Li}-1.5 \mathrm{Al}$, reached $\Delta t=138$ and $104.4 \mathrm{~s}$, respectively.

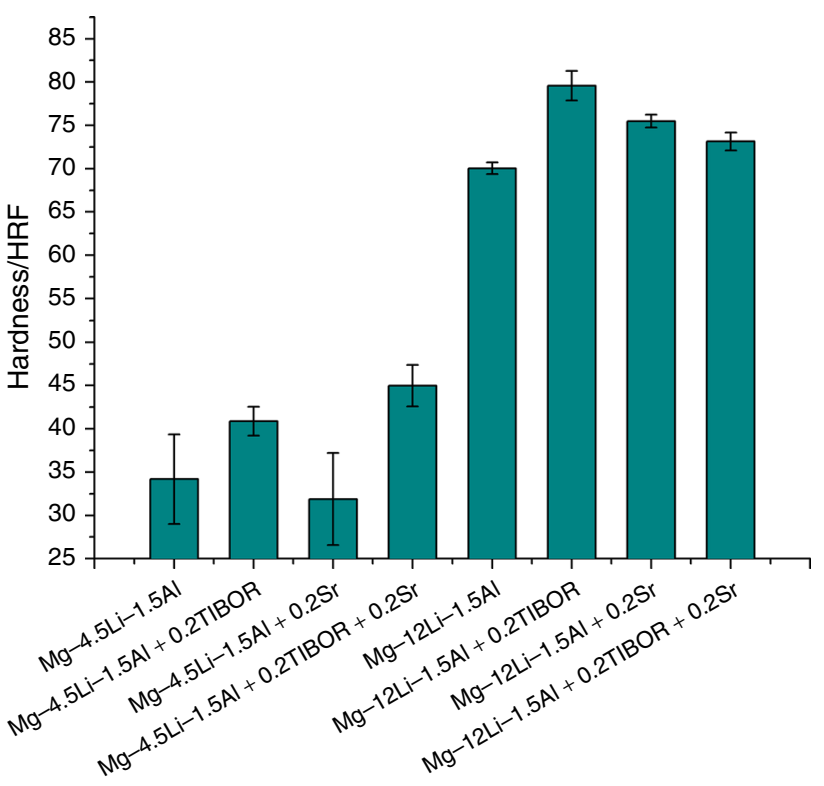

Fig. 6 Variation of hardness of as-cast alloys with the addition of TiB and $\mathrm{Sr}$ grain modifiers

When $\mathrm{TiB}$ and $\mathrm{Sr}$ are added to the analysed alloys, occurrence of new exothermic peak (designated as point 4 in Fig. 7a-d) presumably comes from the crystallisation of 

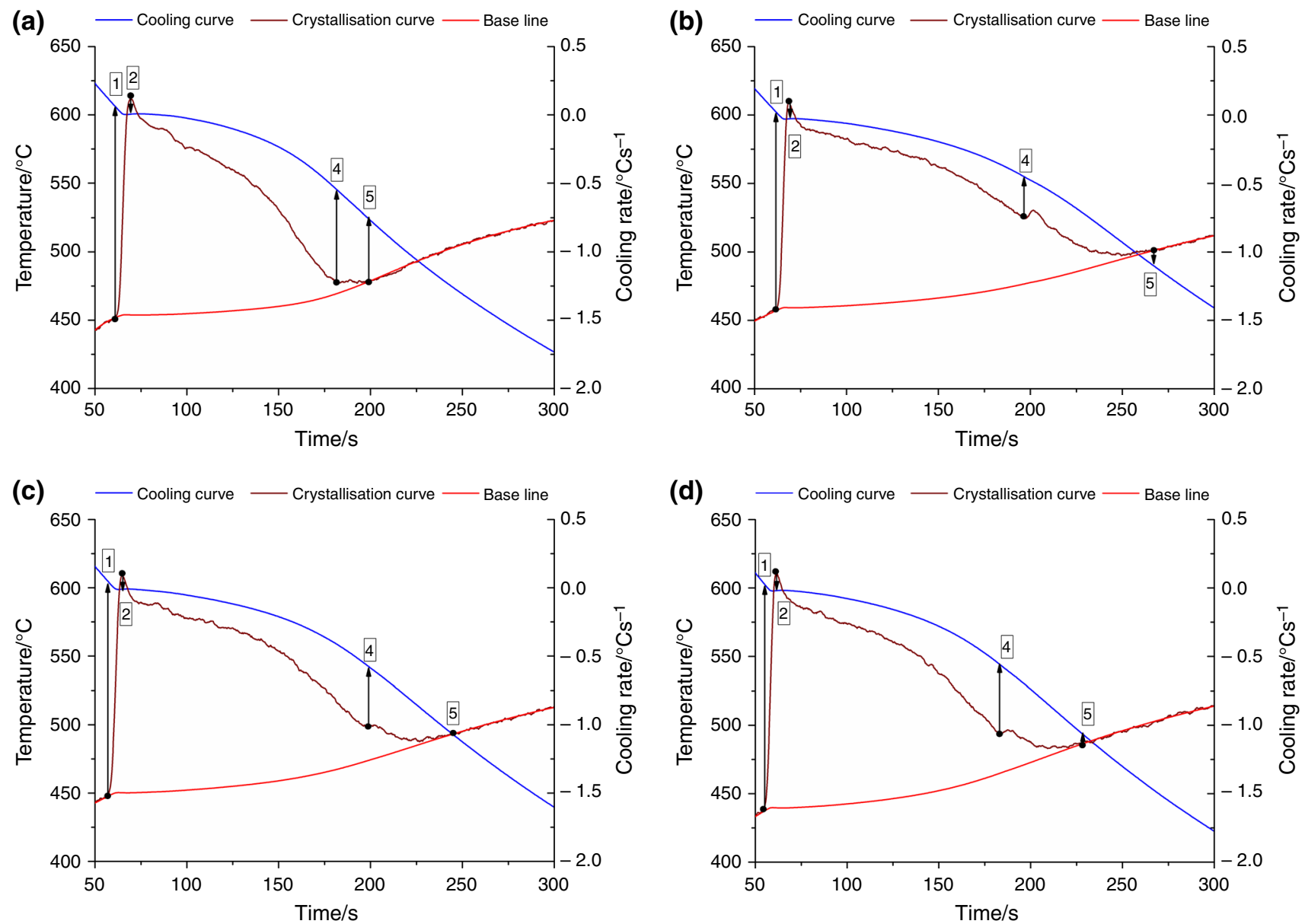

Fig. 7 Thermal-derivative analysis results of: a $\mathrm{Mg}-4.5 \mathrm{Li}-1.5 \mathrm{Al}, \mathbf{b} \mathrm{Mg}-4.5 \mathrm{Li}-1.5 \mathrm{Al}+0.2 \mathrm{TiB}, \mathbf{c} \mathrm{Mg}-4.5 \mathrm{Li}-1.5 \mathrm{Al}+0.2 \mathrm{Sr}, \mathbf{d} \mathrm{Mg}-4.5 \mathrm{Li}-$ $1.5 \mathrm{Al}+0.2 \mathrm{TiB}+0.2 \mathrm{Sr}$

Table 3 Solidification characteristics of modified $\mathrm{Mg}-4.5 \mathrm{Li}-1.5 \mathrm{Al}$ alloy

\begin{tabular}{|c|c|c|c|c|c|}
\hline \multicolumn{2}{|c|}{ Reaction $/{ }^{\circ} \mathrm{C}$} & \multirow{2}{*}{$\begin{array}{l}\mathrm{Mg}-4.5 \mathrm{Li}- \\
1.5 \mathrm{Al} \\
606.06\end{array}$} & \multirow{2}{*}{$\begin{array}{l}\mathrm{Mg}-4.5 \mathrm{Li}- \\
1.5 \mathrm{Al}+0.2 \mathrm{TiB} \\
607.90\end{array}$} & \multirow{2}{*}{$\begin{array}{l}\mathrm{Mg}-4.5 \mathrm{Li}- \\
1.5 \mathrm{Al}+0.2 \mathrm{Sr} \\
605.26\end{array}$} & \multirow{2}{*}{$\begin{array}{l}\mathrm{Mg}-4.5 \mathrm{Li}- \\
1.5 \mathrm{Al}+0.2 \mathrm{TiB}+0.2 \mathrm{Sr} \\
602.51\end{array}$} \\
\hline 1 & $\begin{array}{l}T_{\mathrm{N}} \text {-nucleation temperature (liquidus } \\
\text { temperature) }\end{array}$ & & & & \\
\hline 2 & $T_{\alpha, G}-\alpha-\mathrm{Mg}$ growth temperature & 600.53 & 597.25 & 599.09 & 598.14 \\
\hline 3 & $T_{\beta, G}-\beta$-Li growth temperature & - & - & - & - \\
\hline 4 & $T_{\eta(\mathrm{LiAl})}$-nucleation of $\eta(\mathrm{LiAl})$ phase & 545.38 & 554.49 & 542.46 & 543.55 \\
\hline 5 & $T_{\mathrm{SOL}}$ - solidus temperature & 524.17 & 492.31 & 493.24 & 491.23 \\
\hline
\end{tabular}

$(-)$ reaction not observed

metastable intermetallic phase $\eta(\mathrm{LiAl})$ with $\mathrm{B} 2$ structure [16-18]. $4-T_{\eta(\mathrm{LiAl})}$-nucleation of $\eta(\mathrm{LiAl})$ phase is observed at $554.49{ }^{\circ} \mathrm{C} \quad(\mathrm{Mg}-4.5 \mathrm{Li}-1.5 \mathrm{Al}+\mathrm{TiB})$, $542.46{ }^{\circ} \mathrm{C}(\mathrm{Mg}-4.5 \mathrm{Li}-1.5 \mathrm{Al}+\mathrm{Sr})$ and $543.55^{\circ} \mathrm{C}(\mathrm{Mg}-$ $4.5 \mathrm{Li}-1.5 \mathrm{Al}+0.2 \mathrm{TiB}+0.2 \mathrm{Sr})$.

The crystallisation sequence of analysed $\mathrm{Mg}-4.5 \mathrm{Li}-$ $1.5 \mathrm{Al}$ alloys, based on first derivative analysis, microstructure examination and research of phase diagrams $[16,17]$ may be described as:

1. $L \rightarrow \alpha(\mathrm{Mg})$

2. $\alpha-\mathrm{Mg}$ growth temperature

3. $\alpha(\mathrm{Mg}) \rightarrow \alpha(\mathrm{Mg})+\eta(\mathrm{LiAl})$ 
In the first stage, the hcc of $\alpha(\mathrm{Mg})$ begins to crystallise, until the liquid composition leads to the $\beta$ - Li growth temperature. After passing that temperature, transformation in solid state occurs (solvus line in $\mathrm{Mg}-\mathrm{Li}$ binary system) resulting in appearance of $\alpha(\mathrm{Mg})$ and $\eta(\mathrm{LiAl})$ intermetallic compound with B2 structure. Crystallisation process finished with solidus temperature.

Additions of grain refinements to the $\mathrm{Mg}-12 \mathrm{Li}-1.5 \mathrm{Al}$ alloy result in slight reduction in nucleation temperature to $581.16{ }^{\circ} \mathrm{C}$ (with $\mathrm{TiB}+\mathrm{Sr}$ ) but highly decrease a solidus temperature from 553.48 to $518.07{ }^{\circ} \mathrm{C}$ concerning the unmodified alloy. Based on first derivative analysis (Fig. 8 and Table 4), it was discovered that application of TiB and $\mathrm{Sr}$ simultaneously results in reduction in $T_{\beta, \mathrm{G}}-\beta$ - $\mathrm{Li}$ growth temperature from 580.08 to $573.99{ }^{\circ} \mathrm{C}$.

It is summarised that thermal-derivative analysis did not detect any additional reaction such as precipitation of
$\mathrm{Mg}_{2} \mathrm{Sr}$, with high melting temperature $680{ }^{\circ} \mathrm{C}$ as presented in works $[16,17]$. This situation can be caused that the level of $\mathrm{Mg}_{2} \mathrm{Sr}$ intermetallic phase is very low below the detection level of the method.

The transformation sequences during crystallisation of $\mathrm{Mg}-12 \mathrm{Li}-1.5 \mathrm{Al}$ alloys, based on first derivative, microstructure analysis and study of phase diagrams $[16,17]$ may be described as follows:

1. $L \rightarrow \beta(\mathrm{Li})$

2. $\quad \beta$-Li growth temperature

3. $\beta(\mathrm{Li}) \rightarrow \beta(\mathrm{Li})+\eta(\mathrm{LiAl})$

In the first stage, the $\beta(\mathrm{Li})$ is formed, until the liquid composition reaches the $\beta$-Li growth temperature. Then, transformation in solid state happens causing formation of $\beta(\mathrm{Li})$ phase and $\eta(\mathrm{LiAl})$ intermetallic phase with $\mathrm{B} 2$
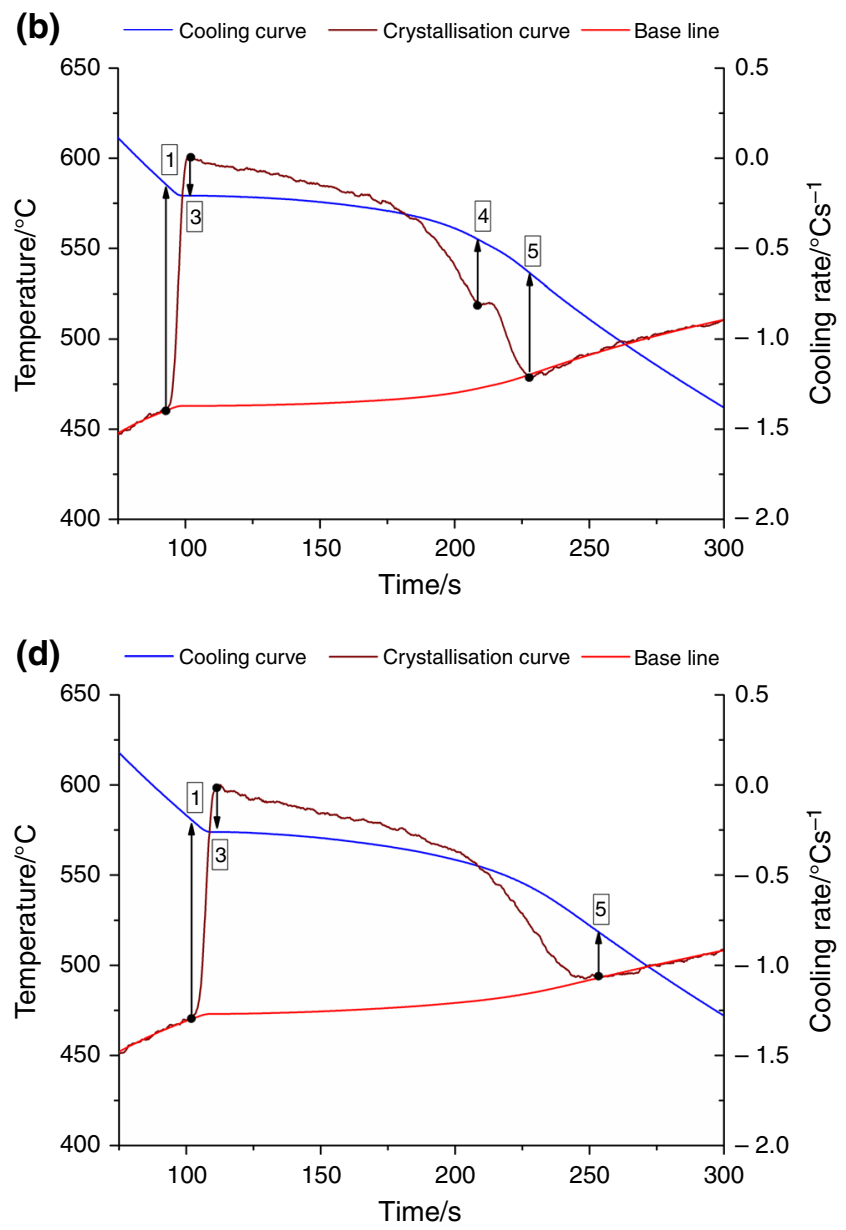

Fig. 8 Thermal analysis results of: a $\mathrm{Mg}-12 \mathrm{Li}-1.5 \mathrm{Al}, \quad$ b $\mathrm{Mg}-12 \mathrm{Li}-1.5 \mathrm{Al}+0.2 \mathrm{TiB}, \quad$ c $\quad \mathrm{Mg}-12 \mathrm{Li}-1.5 \mathrm{Al}+0.2 \mathrm{Sr}, \quad$ d $\quad \mathrm{Mg}-12 \mathrm{Li}-$ $1.5 \mathrm{Al}+0.2 \mathrm{TiB}+0.2 \mathrm{Sr}$ 
Table 4 Solidification characteristics of modified $\mathrm{Mg}-12 \mathrm{Li}-1.5 \mathrm{Al}$ alloy

\begin{tabular}{|c|c|c|c|c|c|}
\hline \multicolumn{2}{|c|}{ Reaction $/{ }^{\circ} \mathrm{C}$} & \multirow{2}{*}{$\begin{array}{l}\mathrm{Mg}-12 \mathrm{Li}- \\
1.5 \mathrm{Al} \\
585.84\end{array}$} & \multirow{2}{*}{$\begin{array}{l}\mathrm{Mg}-12 \mathrm{Li}- \\
1.5 \mathrm{Al}+0.2 \mathrm{TiB} \\
585.83\end{array}$} & \multirow{2}{*}{$\begin{array}{l}\mathrm{Mg}-12 \mathrm{Li}- \\
1.5 \mathrm{Al}+0.2 \mathrm{Sr} \\
583.00\end{array}$} & \multirow{2}{*}{$\begin{array}{l}\mathrm{Mg}-12 \mathrm{Li}- \\
1.5 \mathrm{Al}+0.2 \mathrm{TiB}+0.2 \mathrm{Sr} \\
581.16\end{array}$} \\
\hline 1 & $\begin{array}{l}T_{\mathrm{N}} \text {-nucleation temperature (liquidus } \\
\text { temperature) }\end{array}$ & & & & \\
\hline 2 & $T_{\alpha, \mathrm{G}}-\alpha-\mathrm{Mg}$ growth temperature & - & - & - & - \\
\hline 3 & $T_{\beta, \mathrm{G}}-\beta$-Li growth temperature & 580.08 & 579.26 & 577.8 & 573.99 \\
\hline 4 & $T_{\eta(\mathrm{LiAl})}$-nucleation of $\eta(\mathrm{LiAl})$ phase & - & 554.97 & 539.16 & - \\
\hline 5 & $T_{\mathrm{SOL}}$-solidus temperature & 553.48 & 536.61 & 522.36 & 518.07 \\
\hline
\end{tabular}

$(-)$ reaction not observed

structure (reaction registered for $\mathrm{Mg}-12 \mathrm{Li}-1.5 \mathrm{Al}+0.2$ $\mathrm{TiB}$ and $\mathrm{Mg}-12 \mathrm{Li}-1.5 \mathrm{Al}+0.2 \mathrm{Sr}$ alloys $)$.

\section{Conclusions}

The crystallisation sequence of $\mathrm{Mg}-\mathrm{Li}-\mathrm{Al}$ alloys has been investigated in detail by using thermal-derivative analysis and microstructural observations. The results are summarised as follows:

1. The $\mathrm{TiB}$ and $\mathrm{Sr}$ grain modifiers improve the microstructure of the resulting alloy. The application of $\mathrm{TiB}$ and $\mathrm{Sr}$ refines the grain of $\alpha-\mathrm{Mg}$, the grain size becomes smaller and the morphology of the grains is a small spherical crystal.

2. Microstructure and XRD analysis show that the application of $\mathrm{TiB}$ and $\mathrm{Sr}$ does not change structural and phase composition of analysed ultralight alloys. The as-cast $\mathrm{Mg}-4.5 \mathrm{Li}-1.5 \mathrm{Al}$ alloy comprises $\alpha(\mathrm{Mg})$ phase and $\mathrm{Mg}-12 \mathrm{Li}-1.5 \mathrm{Al}$ is composed of $\beta(\mathrm{Li})$ phase.

3. The solidification time of analysed alloys is increased by increasing the Li content.

4. The most potent effect on hardness was observed when $\mathrm{TiB}$ as a grain refinement was added. The hardness of $\mathrm{Mg}-4.5 \mathrm{Li}-1.5 \mathrm{Al}$ rises from 34 to $40 \mathrm{HRF}$, and hardness of $\mathrm{Mg}-12 \mathrm{Li}-1.5 \mathrm{Al}$ rises from 70 to $79 \mathrm{HRF}$.

5. Based on the results of TDA, a crystallisation process of $\mathrm{Mg}-\mathrm{Li}-\mathrm{Al}$ alloys was proposed. Addition of grain refinements to the alloy with 4.5 mass $\%$ of $\mathrm{Li}$ causes a decrease in nucleation, slightly $\mathrm{Mg}$ growth temperature and strongly solidus temperature, as well as increase in the crystallisation range of the alloy from $82{ }^{\circ} \mathrm{C}$ to over $110^{\circ} \mathrm{C}$. Analysis of thermal results of the alloy containing 12 mass $\%$ of lithium shows that addition $\mathrm{TiB}$ and $\mathrm{Sr}$ causes reduction in nucleation temperature, $\mathrm{Li}$ growth temperature and strongly solidus temperature. Thermal analysis of the alloys containing 12 mass \% of $\mathrm{Li}$ revealed that the crystallisation range of the alloy increases from approx. $30{ }^{\circ} \mathrm{C}$ to over $60{ }^{\circ} \mathrm{C}$.

6. Application of thermal-derivative analysis to characterise a solidification pathway of $\mathrm{Mg}-\mathrm{Li}-\mathrm{Al}$ alloys has large potential in the field of heat treatment and casting processes such as semisolid metal casting.

Acknowledgements The research was partially financed within the framework of the National Center for Science Project No. DEC-2017/ 01/X/ST8/01900 headed by Dr Mariusz Król.

Open Access This article is distributed under the terms of the Creative Commons Attribution 4.0 International License (http://creative commons.org/licenses/by/4.0/), which permits unrestricted use, distribution, and reproduction in any medium, provided you give appropriate credit to the original author(s) and the source, provide a link to the Creative Commons license, and indicate if changes were made.

\section{References}

1. Jafari H, Khalilnezhad M, Farahany S. Computer-aided cooling curve thermal analysis and microstructural evolution of $\mathrm{Mg}-5 \mathrm{Zn}-$ $x Y$ cast alloys. J Therm Anal Calorim. 2017;130(3):1429-37.

2. Sroka M, Zieliński A, Hernas A, Kania Z, Rozmus R, Tański T, Śliwa A. The effect of long-term impact of elevated temperature on changes in the microstructure of Inconel $740 \mathrm{H}$ alloy. Metalurgija. 2017;56(3-4):333-6.

3. You S, Huang Y, Kainer KU, Hort N. Recent research and developments on wrought magnesium alloys. J Magnes Alloys. 2017;5(3):239-53.

4. Pan F, Yang M, Chen X. A review on casting magnesium alloys: modification of commercial alloys and development of new alloys. J Mater Sci Technol. 2016;32(12):1211-21.

5. Joosta WJ, Krajewski PE. Towards magnesium alloys for highvolume automotive applications. Scripta Mater. 2017;128:107-12.

6. Krupinski M, Krupinska B, Labisz K, Rdzawski Z, Tanski T. Effect of chemical composition modification on structure and properties of the cast $\mathrm{Zn}-\mathrm{Al}-\mathrm{Cu}$ alloys. P I Mech Eng L-J Mat. 2016;230(3):805-12.

7. Risueño E, Gil A, Rodríguez-Aseguinolaza J, Gil A, Tello M, Faik A, D'Aguanno B. Thermal cycling testing of $\mathrm{Zn}-\mathrm{Mg}-\mathrm{Al}$ eutectic metal alloys as potential high-temperature phase change 
materials for latent heat storage. $\mathrm{J}$ Therm Anal Calorim. 2017;129(2):885-94.

8. Luo AA. Magnesium casting technology for structural applications. J Magn Alloys. 2013;1(1):2-22.

9. Regenera D, Tkachenko V. Strength characteristics of $\mathrm{Mg}-\mathrm{Li}$ alloys. Strength Mater. 2009;41:294-302.

10. Król M, Staszuk M, Mikuszewski T, Kuc D. Refinement effect of $\mathrm{RE}$ in light weight $\mathrm{Mg}-\mathrm{Li}-\mathrm{Al}$ alloys. J Therm Anal Calorim. 2018;13(1):333-41. https://doi.org/10.1007/s10973-018-7290-z.

11. Król M, Tański T, Matula G, Snopiński P, Tomiczek AE. Analysis of crystallisation process of cast magnesium alloys based on thermal derivative analysis. Arch Metall Mater. 2015;60(4):2993-9. https://doi.org/10.1515/amm-2015-0478.

12. Krupińska B, Rdzawski Z. Effect of Re addition of solidification and heat treatment on the $\mathrm{Cu}-\mathrm{Ni}-\mathrm{Si}$ alloy structure. J Therm Anal Calorim. 2018;134(1):173-9.

13. Zieliński A, Sroka M, Hernas A, Kremzer M. The effect of longterm impact of elevated temperature on changes in microstructure and mechanical properties of HR3C steel. Arch Metall Mater. 2016;61(2A):761-6. https://doi.org/10.1515/amm-2016-0129.

14. Yavari F, Shabestari SG. Effect of cooling rate and Al content on solidification characteristics of AZ magnesium alloys using cooling curve thermal analysis. J Therm Anal Calorim. 2017;129:655-62. https://doi.org/10.1007/s10973-017-6240-5.

15. Nayeb-Hashemi AA, Clark JB, Pelton AD. Bull Alloy Phase Diagr. 1984;5(4):365-74.

16. Goel NC, Cahoon JR. Bull Alloy Phase Diagr. 1990;11:528. https://doi.org/10.1007/BF02841712.

17. A.I.H. Committee (1992) ASM Handbook, vol 3: Alloy Phase Diagrams, tenth edn., The Materials Information Company.

18. Król M. Effect of grain refinements on the microstructure and thermal behaviour of $\mathrm{Mg}-\mathrm{Li}-\mathrm{Al}$ alloy. $\mathrm{J}$ Therm Anal Calorim. 2018;133(1):237-46. https://doi.org/10.1007/s10973-018-7223-x.

Publisher's Note Springer Nature remains neutral with regard to jurisdictional claims in published maps and institutional affiliations. 